\title{
ANALYSIS OF SELECTED FACTORS AFFECTING THE INCREASE OF EMPLOYEE PERFORMANCE
}

\section{Zuzana HAJDUOVÁ}

Faculty of Business Management, University of Economics in Bratislava, Slovakia

$$
\text { František SEBESTYÉN }
$$

Faculty of Business Management, University of Economics in Bratislava, Slovakia

Received: 04. April 2021 Reviewed: 29. May 2021 Accepted: 15. June 2021

\begin{abstract}
Focusing on human resources is considered to be a priority that the management of companies have an obligation to enshrine in the strategy of the organization. This segment is a key element of business development. Human resources change the competitiveness of businesses. The presented work deals with the identification of individual factors that affect employee satisfaction. It is necessary, the management of companies changed the attitude towards employees. The aim of the research was to identify the existing differences in the perception of financial and non-financial benefits from the perspective of women and men. The employee remuneration strategy is a complex system, important both for the employer and the employee. The aim of this work is to provide a global view on the issue of employee satisfaction, motivation for better performance, but also to examine the perspectives of the remuneration system in terms of gender by applying quantitative research methods. An effective remuneration system increases the loyalty and quality of employee performance and consequently increases companies' competitiveness. If the needs of employees are precisely identified, personal development takes place and employee fluctuation is avoided, which results in increased efficiency and better performance.
\end{abstract}

Keywords: human resources, motivation, financial benefits, non-financial benefits

JEL Classification: J33, C52, M51

\section{Introduction and theoretical background}

Strategic management in a selected company represents the continuity and coherence of fundamental decisions. It is a matter of harmonizing the defined variables of the external environment with the internal parameters of the examined company. It is about the implementation of strategic management rules that result in the determina- 
tion of three basic variables of the company - success, growth and sustainability. Each prosperous company creates the best possible position in a competitive market, and also strives to achieve the highest possible profit to meet its predetermined goals.

In order to achieve the desired growth of the company, employees are considered to be a decisive factor of success. Human resources management practices are critical and valuable assets of companies (Belas, Kmecova, Cepel, 2020), and their high quality management can lead to improved business performance processes, competitive advantage and increased organizational performance (Ahsan et al., 2013). When it comes to efficiency or the success of organizations, the key role is played by human resources. Instead of directly influencing the company's indicators on financial performance, human resources practices have a positive impact on other phenomena affecting the performance of the company. Personnel practices can affect the performance of a company on collective level by improving organizational skills, culture, social and psychological climate in the company. Since the success of business processes depends on the success of individuals, the collective performance of individuals will determine the success of the organization. Practices in the field of HR manage business performance by influencing through the impact on knowledge, skills, abilities and further characteristics that are relevant to perform a particular job, willingness of the individual to fulfil, and opportunities to express talent (Arvanitis et al., 2015). The practices in the field of human resources can be designed to support the development of the appropriate skills of sales staff through training and development, manage certain business activities with the help of remuneration policy, and to ensure adequate resources to conduct all of these activities (Massingham, 2015).

Work motivation and satisfaction are closely linked. Armstrong (2019) defines job satisfaction as a combination of attitudes and feelings that people experience in connection to their work. According to Carter (2012), satisfaction cannot be precisely defined, it can be understood as satisfaction with work and work conditions. An employee can perceive satisfaction in different ways. It can represent self-realization, joy of the work performed combined with satisfying personal needs. Job satisfaction is reflected in specific attitudes, evaluation of certain work, and the level of certain work conditions. Different factors might have different impact on the employee, and at the same time affect employee satisfaction with different degrees of intensity.

Hiring and retaining quality employees requires the employer to assess the quality of their work fairly and effectively. Motivating remuneration is an effective way to reward employees, which is one of the crucial tasks of human resources management (Mura, Vlacseková, 2018; Kleina, Štāle, 2019; Ližbetinová, Hitka, 2020). It is essential that the remuneration system reflects employee performance in different positions, as it has an impact on their further performance and satisfaction. The article is addressing the issue of employee motivation. It focuses on the system and structure of motivation factors in the company. The properly set system of factors that stimulate employee motivation is a challenging task. The key problem is to set up a system, which is adequate, fair and balanced. In particular, the remuneration system should respect the requirements both of the company and the employee. Not only do companies have their own structure and division of positions, they also have company structure and characteristic relationships with their employees. Individual businesses use set tools to achieve the defined goals. However, the fact is that employees are people who have their own preferences and needs.

Human resources management applies to all practices and policies that deal with personnel issues in organizations. Human resources management practices are nowadays crucial and valuable assets in businesses, and their high quality management 
can lead to improved performance of business processes, competitive advantage and increased performance of the organization. The main goal of companies in terms of human resources management is to maintain, motivate and attract employees, who are talented and loyal to the company (Stone et al., 2015). Personnel strategy is one of the partial strategies of organizations, expressing the future intentions of the organization (Szeiner et al, 2020; (Močarníková, Mucha, Peráček, 2018), the long-term and complex goals in the field of human resources management (in line with the other goals of the organization), which can contribute to achieve organizational goals. The personnel strategy must respond to changes in an organization's strategy, must correspond to the specifics of the organization, respect the internal conditions in which the organization operates (Wang, 2016).

Well-known models of human resources help us explain the position of solving the issue of human resources in the organization. They emphasize, in particular, the added value of human resources and how they affect efficiency and performance. The most important models are the following:

- Standard casual model of HRM

- Model - Paul Boselie

- Value chain - Paauwe and Richardson

- Harvard framework

\section{Figure 1 Harvard Framework for Human Resource Management}

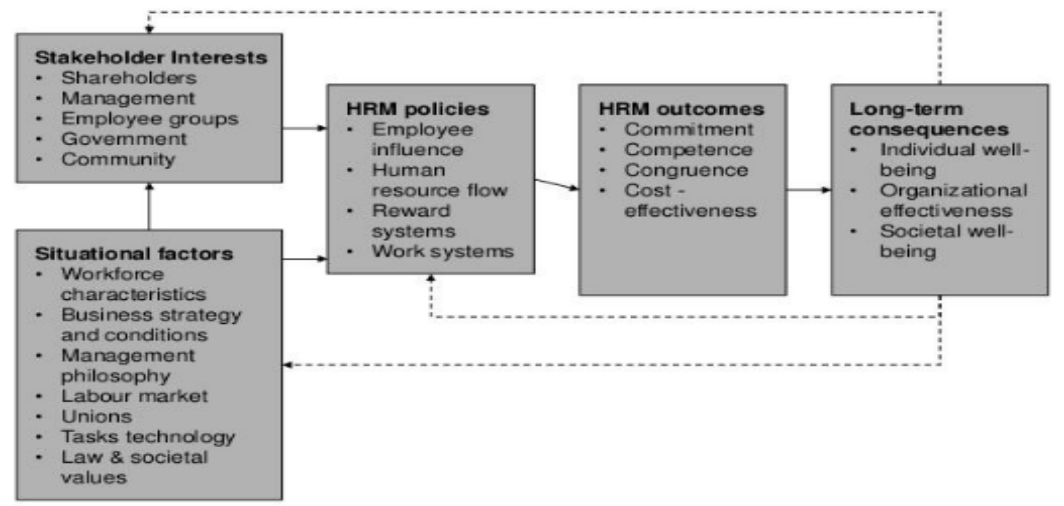

Source: Beer et al., 1984

Our work is addressing the Harvard framework. The model is based on the principle of interest of different stakeholders. The interests of these stakeholders are influenced by situational factors. Situational factors have a character of workforce. Stakeholders together with situational factors directly influence the processes of human resources - recruitment, training and the system of remuneration. If these activities are properly conducted, they lead to positive results. If a company manages to keep at minimum values, employees are motivated and employee turnover is manageable. These results also lead to long-term results - individual, organizational and social. The Harvard model takes more general approach to HR, including results at different levels (Figure 1). 
In the long run, the effort to increase the level of organization and the society is based on the management of human resources (Kruss et al,, 2015; McDonell et al., 2014). The basic condition for human resources development in organizations is the establishment of a climate of trust, openness and motivation, which contributes to the personal growth of the individual as well as their increased performance (Gelens et al., 2014). Employee motivation leads to visible and measureable parameters e.g. workplace promotion, higher remuneration and employee satisfaction. The organization will have a lower rate of employee turnover (Singh et al., 2009). The role of company leaders and managers is to identify the potential of the employee, as well as to create space for motivation and development of key competencies of their employees. Remuneration is a strong motivation factor. According to research projects implemented so far, the highest limits of employees are perceived within the motivational factor of remuneration. Recent research results show that employees motivated by financial incentives will perform more efficiently if the organization pays more. However, some experts doubt the importance of money as an incentive. It is acceptable, but finances are the primary source of motivation and stimulus system (Armstrong, 2009).

In the case of financial remuneration, the aspect of individual approach and personalization is very important (Tetik, 2017). It is up to the organization to consider what types of financial as well as non-financial incentives the employees prefer and to determine their proportionality. Remuneration can be differentiated in terms of fixed and variable components, but other benefits should be included as well (Schlechter et al., 2014). Several studies support the opinion that in addition to basic benefits and remuneration, the quality of the work environment and work-life balance are also motivating factors. Emphasis is placed on employee development, the learning abilities of individuals, which is closely linked to the overall excellence of an organization (Tan, 2013).

New approaches to this issue mention employee motivation in terms of creativity, proposing own innovations and innovative ideas. It is a creative environment that also initiates increased performance among other team members. The determinants of motivation should be closely linked to the specific tasks of an employee at a given level of development. An employee, being a part of a team, which is referred to be creative by the company management is a motivating factor that an employee values more than receiving a financial benefit (Swailes, Blackburn, 2016). Talented and creative employees can be found in small businesses, mainly in start-ups (Peráček et al., 2018). Remuneration can be provided in the form of delegating an important task to an employee, which results in enhanced social status within a team.

The combination of financial and non-financial benefits leads to increased employee motivation and higher quality work performance. This is reflected in increased financial performance of the company and its better competitiveness in the market. Delery and Doty (1996) identified seven strategic approaches in the field of human resources that are associated with the organizational performance: internal job opportunities, formal training systems, evaluation measures, sharing the profit, job security, voice mechanisms and the definition of workplaces. Pfeffer (1998) categorized seven practices or best practices: job security, selective recruitment process, self-managed teams or teamwork, high wages linked to company performance, trainings, and decreasing disparities in the field of information sharing.

Managers play an important role in the motivation process, as they must be able to motivate their subordinates with the appropriate tools of motivation, utilize effectively the motivation processes offered by the company. It is crucial to understand the motivation process and how these processes work. The theories of motivation help 
managers better understand employee behaviour in certain situations. Unfortunately, no theory provides a general rule of thumb to explain human behaviour. If an employee does not provide satisfactory performance, it is usually associated with inadequate motivation. Therefore, managers should be aware of basic principles and types of motivation, so that their approach to employee motivation would be based on theory, applicable in certain work situations (Dvořáková et al., 2012).

\section{Material and methods}

The aim of this paper is to get a global insights into the issue of employee satisfaction and motivation to achieve increased performance, but also an insight into the remuneration system from gender perspective. A quantitative research was applied to obtain data.

A wide variety of scientific literature was used to form the theoretical background to the discussed issue. As a secondary source, the scientific literature dominated with a focus on up-to-date research results of authors and professionals registered in the Scopus and Web of Science databases. In addition, the papers of domestic and further authors, professionals were used. As a primary source of information we have to mention the information obtained by conducting a questionnaire survey, data collected primarily as a part of field research.

The basic research method applied was a questionnaire survey. Questionnaire surveis are a method often applied in quantitative research, because they provide a primary source of data and feedback, which is one of the most important components of the system. The benefit of this method is using statistical software for analysis, while the disadvantages are the insufficient sample size, failure to meet some assumptions resp. inappropriate choice of the sample, and problems with the credibility of responses. The information obtained by a questionnaire survey has to be processed, for which we used the methods presented below. If we want to describe the correlation between two variables, the correlation coefficient is applied as the following:

$$
r_{x y}=\frac{\overline{x y}-\bar{x}, \bar{y}}{\sqrt{\left(\overline{x^{2}}-\bar{x}^{2}\right)}\left(\overline{y^{2}}-\bar{y}^{2}\right)}
$$

The correlation coefficient takes a value from interval $\langle-1,1\rangle$. The direction

of the dependence is determined by the coefficient. If $r_{x y}>0$, we talk about direct dependence. As the values of the variable $x$ increase, the values of the variable $y$ ten

to increase too. If $r_{x y}<0$, we talk about indirect independence. As the values of

the variable $x$ increase, the values of the variable $y$ tend to decrease. If $r_{x y}=0$, both variables are linearly independent. 
Such variables are said to be uncorrelated. We will consider as significant values at least a mild correlation, i.e. higher than 0,3 and less than $-0,3$ in the case of indirect correlation. A strong correlation can be considered when the values of the coefficient are higher than 0,5, resp. lower than -0,5. (Efron, 1992).

According to Spiwok (2015), one of the ways to use the results of the sample survey to better understand the characteristics of the basic sample is to test the statistical hypotheses. Hypotheses in statistics are certain assumptions about the basic features of the surveyed random variables. The most common assumptions are about the type resp. the parameters of distribution. The hypothesis we would like to verify is the basic (null) hypothesis and is called H0. Against the basic hypothesis we set the alternative hypothesis H1, which is an alternative assumption (in most of the cases negation) of the researched feature. The purpose of statistical testing of hypotheses is the decision to reject $H_{0^{\prime}}$ resp. not to reject $H_{0^{\prime}}$ (in favour of $H_{1}$ ).

- The following main tests on hypotheses are recognized:

- Tests of mean values and tests of comparison of two mean values

- Tests on shares and tests on comparing two shares

- Variance tests and tests comparing two variances

$$
\begin{gathered}
P\left(\bar{x}-t_{1-\frac{\alpha}{2}, n-1} \frac{s}{\sqrt{n}}<\mu<\bar{x}+t_{1-\frac{\alpha}{2}, n-1} \frac{s}{\sqrt{n}}\right)=1-\alpha \\
P\left(\infty<\mu<\bar{x}+t_{1-\alpha, n-1} \frac{s}{\sqrt{n}}\right)=1-\alpha \\
P\left(\bar{x}-t_{1-\alpha, n-1} \frac{s}{\sqrt{n}}<\mu<\infty\right)=1-\alpha
\end{gathered}
$$

\section{Results and discussion}

The original research was conducted in 2015. It was repeated at the request of practice, the motivation and satisfaction of employees in relation to performance was measured. Since this study was extensive, in this work we present only part of the relevant results. Gender equality and the gender status of women is a highly discussed issue. We decided to target this issue since we also detected the presence of discrimination against women. The basic group was formed by employees in a selected region of Slovakia. The questionnaires were sent to respondents and filled in voluntarily. A total of 32 companies were contacted and 5 of these companies did not respond to the survey. The final number of returned questionnaires was 127, 48 male and 79 female respondents. The description of the examined sample is presented on Figure 2. 
Figure 2 Description of the examined sample
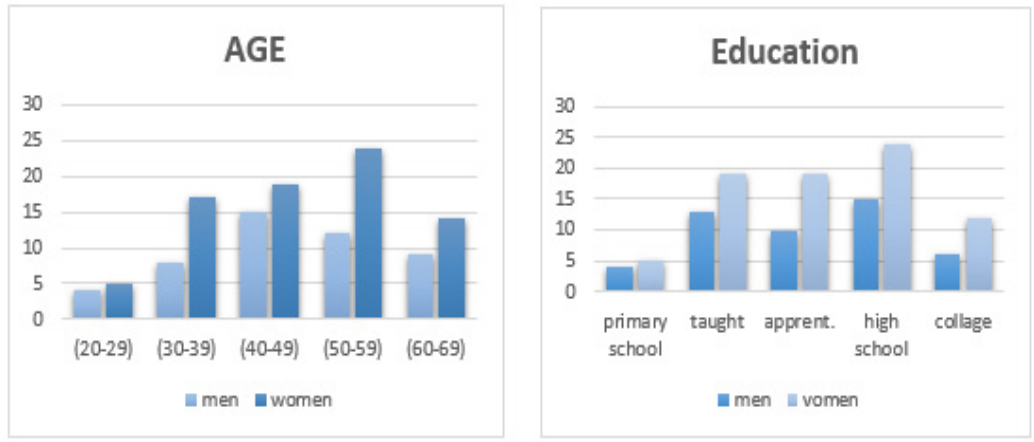

Source: own processing

Regarding the research sample, first we were trying to find correlations between variables such as age, achieved qualification in three basic segments, job satisfaction, financial remuneration and fringe benefits, examining both male and female respondents. Based on statistical evaluation, we can confirm that the higher the respondents' qualification is, the higher their satisfaction with their work. The value of correlation coefficient is $r=0,485$, which means mean dependence. In the segment of achieved qualification we came to conclusion that the lower the respondents' education is, the higher the job satisfaction of the respondent is. The value of correlation analysis is $r=-$ 0,463 . Following the overall analysis of motivation factors we can assess that the most important motivation factor are financial benefits $(72 \%)$, followed by working in a good team and personal evaluation $(19 \%)$. It is necessary to mention that continuous learning and trainings organized by the employer were not found attractive by the respondents. This is an interesting finding for the company management since these activities should be made attractive and financially rewarded by the management.

In this work we present only a small part of our findings, which are presented from the perspective of the hypotheses set.

$H_{1}$ : There is a statistically significant difference in the perception of job satisfaction between women and men.

We applied a questionnaire survey to determine job satisfaction. The respondents were asked to evaluate the individual aspects of job satisfaction on a five-point scale. The individual factors were determined with the help of a work team made up of experts in labour law and psychology. The factors we set were evaluated with the help of a questionnaire. Some of them are being introduced or under development e.g. good workplace relationships, cooperation in problem solving, adequate utilization of the employee skills and knowledge, cooperation with superiors, delegated decision-making in partial tasks, implementation of own innovative ideas, organization of work and work perspectives. The questions focused on work - my work is my hobby, my work is interesting, my current job satisfies my needs, my work is boring, I do not like my job. We applied a T-test for statistical evaluation. The results are presented in Table 1. 
Table 1 T-test to compare satisfaction in gender breakdown

\begin{tabular}{|r|r|r|r|r|r|}
\hline $\mathbf{N}$ & Mean & Std Dev & Std Err & Minimum & Maximum \\
\hline 48 & 2.6667 & 1.1910 & 0.1719 & 1.0000 & 5.0000 \\
\hline 79 & 2.4810 & 1.2389 & 0.1394 & 1.0000 & 5.0000 \\
\hline 0.1857 & 1.2211 & 0.2235 & & \\
\hline
\end{tabular}

\begin{tabular}{|l|r|r|r|r|r|r|}
\hline Method & Mean & 95\% CL Mean & Std Dev & 95\% CL Std Dev \\
\hline & 2.6667 & 2.3208 & 3.0125 & 1.1910 & 0.9915 & 1.4918 \\
\hline & 2.4810 & 2.2035 & 2.7585 & 1.2389 & 1.0713 & 1.4692 \\
\hline Pooled & 0.1857 & -0.2566 & 0.6279 & 1.2211 & 1.0867 & 1.3938 \\
\hline Satterthwaite & 0.1857 & -0.2533 & 0.6246 & & & \\
\hline
\end{tabular}

\begin{tabular}{|l|l|r|r|r|}
\hline Method & Variances & DF & $\mathrm{t}$ Value & $\mathrm{Pr}>|\mathrm{t}|$ \\
\hline Pooled & Equal & 125 & 0.83 & 0.4077 \\
\hline Satterthwaite & Unequal & 102.44 & 0.84 & 0.4035 \\
\hline
\end{tabular}

\begin{tabular}{|c|c|c|c|c|}
\hline \multicolumn{5}{|c|}{ Equality of Variances } \\
\hline Method & Num DF & Den DF & F Value & $\operatorname{Pr}>F$ \\
\hline Folded F & 78 & 47 & 1.08 & 0.7808 \\
\hline
\end{tabular}

Source: own processing

In this case we cannot reject the hypothesis about the equality of variances, as well as we cannot reject the hypothesis on equality of means either, since the p-value for equal variances is 0,4077 . This means that it is not possible to confirm a statistically significant difference between the evaluation of job satisfaction in terms of male and female respondents. Based on the quantified results obtained, Hypothesis 1 was not approved.

$\mathrm{H}_{2}$ There is a statistically significant difference between men and women in the perception of financial remuneration in terms of workplace positions.

Table 2 T-test for comparing financial remuneration from the perspective of men and women

\begin{tabular}{|r|r|r|r|r|r|}
\hline $\mathbf{N}$ & Mean & Std Dev & Std Err & Minimum & Maximum \\
\hline 48 & 3.7292 & 1.0260 & 0.1481 & 1.0000 & 5.0000 \\
\hline 79 & 4.0886 & 0.8502 & 0.0957 & 2.0000 & 5.0000 \\
\hline & -0.3594 & 0.9203 & 0.1684 & & \\
\hline
\end{tabular}

\begin{tabular}{|l|r|r|r|r|r|r|}
\hline Method & Mean & 95\% CL Mean & Std Dev & 95\% CL Std Dev \\
\hline & 3.7292 & 3.4312 & 4.0271 & 1.0260 & 0.8541 & 1.2852 \\
\hline & 4.0886 & 3.8982 & 4.2790 & 0.8502 & 0.7352 & 1.0082 \\
\hline Pooled & -0.3594 & -0.6928 & -0.0261 & 0.9203 & 0.8189 & 1.0504 \\
\hline Satterthwaite & -0.3594 & -0.7099 & -0.00893 & & & \\
\hline
\end{tabular}

\begin{tabular}{|l|l|r|r|r|}
\hline Method & Variances & DF & $\mathrm{t}$ Value & $\mathrm{Pr}>|\mathrm{t}|$ \\
\hline Pooled & Equal & 125 & -2.13 & 0.0348 \\
\hline Satterthwaite & Unequal & 85.435 & -2.04 & 0.0446 \\
\hline
\end{tabular}

\begin{tabular}{|l|r|r|r|r|}
\hline \multicolumn{5}{|c|}{ Equality of Variances } \\
\hline Method & Num DF & Den DF & F Value & Pr > F \\
\hline Folded F & 47 & 78 & 1.46 & $<.0001$ \\
\hline
\end{tabular}

Source: own processing 
Remuneration is a complex system of tools, which is applied in the field of human resources management. There is no uniform model applied by companies achieving the same results. It is clear that employees prefer financial remuneration to non-financial benefits. According to research results, higher wages result in higher remuneration, financial incentive or bonus. The verification of this hypothesis has led to a surprising conclusion that women prefer financial remuneration to a greater extent than their male counterparts, which is probably due to gender differences between the male and female respondents. A T-test was performed for statistical evaluation of the results, which is presented in Table 2 .

The test for equality of variances, where the null hypothesis is that variances are equal, the alternative hypothesis is the inequality of variances. Since the p-value is lower than the significance value, the null hypothesis of equality of variances is rejected. In Table 2 we examine the row of unequal variances. Based on the p-value being 0,0446 , which is less than the significance value at 0,05 , it can be proved with $95 \%$ probability that there is a statistically significant difference between the mean values in terms of financial remuneration based on gender categorization. As the mean value is higher in the case of female respondents, it can be summarized that the aspect of financial remuneration is more important for the female than male respondents. We can state that there are significant differences in the perception of financial remuneration between men and women, according to which Hypothesis 2 is approved.

$\mathrm{H}_{3}$ There is a statistically significant difference between men and women in the perception of non-financial benefits as a part of remuneration.

The research addressed the significance of non-financial benefits from the perspectives of men and women. Flexitime, self-realization, career advancement, workplace recognition, possibility of lifelong learning, responsibility and working in a good team were listed as non-financial benefits.

An open question was provided for the respondents to list further benefits, from which we have chosen the following - company image, security and stability of the company, chance, and work prestige. We applied a t-test for statistical evaluation, the results are presented in Table 3.

Table 3 T-test to compare non-financial benefits from the perspective of female and male respondents

\begin{tabular}{|r|r|r|r|r|r|}
\hline $\mathbf{N}$ & Mean & Std Dev & Std Err & Minimum & Maximum \\
\hline 48 & 3.3125 & 1.3394 & 0.1933 & 1.0000 & 5.0000 \\
\hline 79 & 2.6962 & 1.5472 & 0.1741 & 1.0000 & 5.0000 \\
\hline & 0.6163 & 1.4725 & 0.2695 & & \\
\hline
\end{tabular}

\begin{tabular}{|l|r|r|r|r|r|r|}
\hline Method & Mean & 95\% CL Mean & Std Dev & 95\% CL Std Dev \\
\hline & 3.3125 & 2.9236 & 3.7014 & 1.3394 & 1.1150 & 1.6777 \\
\hline & 2.6962 & 2.3497 & 3.0427 & 1.5472 & 1.3378 & 1.8347 \\
\hline Pooled & 0.6163 & 0.0830 & 1.1496 & 1.4725 & 1.3104 & 1.6807 \\
\hline Satterthwaite & 0.6163 & 0.1008 & 1.1318 & & & \\
\hline
\end{tabular}

\begin{tabular}{|l|l|r|r|r|}
\hline Method & Variances & DF & $\mathrm{t}$ Value & $\mathrm{Pr}>|\mathrm{t}|$ \\
\hline Pooled & Equal & 125 & 2.29 & 0.0239 \\
\hline Satterthwaite & Unequal & 110.38 & 2.37 & 0.0196 \\
\hline
\end{tabular}

\begin{tabular}{|l|r|r|r|r|}
\hline \multicolumn{4}{|c|}{ Equality of Variances } \\
\hline Method & Num DF & Den DF & F Value & $\mathrm{Pr}>$ F \\
\hline Folded F & 78 & 47 & 1.33 & 0.2874 \\
\hline
\end{tabular}

Source: own processing 
The mean values of differences were statistically significant and different. As difference was higher in absolute terms in the case of men, this means that our male respondents evaluated the non-financial benefits better than women. Although the variances were the same based on the test, the hypothesis on the equality of means was rejected. There are significant differences in the perception of non-financial benefits in terms of genders, and based on the quantified results, Hypothesis 3 is approved.

\section{Conclusion}

The presented work is focusing on the analysis of differences between the male and female respondents as employees. The aim of this work was to provide a global insights into the issue of employee satisfaction, motivation to improve employee performance, and the system of remuneration in terms of gender. Information about job satisfaction was obtained by asking the opinion of the respondents. Employee opinion figures as a reflection of employee needs, expectations, but also reflected the perception of work conditions from the perspective of our respondents. The priority of the employer is to know these values, priorities and attitude of the employee. The analysis shows that employees prefer security and stability of the company. Financial remuneration should reflect the achieved performance, results and personal skills. The female respondents perceived financial benefits as a sensitive issue, while our male respondents preferred non-financial benefits. The management of the company should clearly set employee remuneration in the company strategy. The tendency to introduce non-financial benefits is on increase. Regardless to the nature of work, the most enjoyed non-financial benefits in all the selected sectors are company events, home office, flexitime and recreational vouchers. An appropriate system of non-financial benefits might attract potential employees as well as increase the competitiveness of the company. The interest in human resources is considered to be a solid foundation of a prosperous and efficient company. Investing in building a permanent team is a key to business success.

\section{Bibliography}

1. Ahsan, N., Fie, D. Y. G., Foong, Y, P., \& Alam, S. S. (2013). Relationship between retention factors and affective organisational commitment among knowledge workers in Malaysia. Journal of Business Economics and Management, 2013, 14(5), 903-922.

2. Arvanitis, S., Lokshin, B., \& Mohnen, P. (2015). Impact of External Knowledge Acquisition Strategies on Innovation: A Comparative Study Based on Dutch and Swiss Panel Data. Review of Industrial Organization, 46(4), 359-382. doi: 10.1007/ s11151-015-9450-7.

3. Armstrong, M. (2009). Armstrong'sHandbook of Human Resource Management Practice. 11th Edition. London: Kogan Page, ISBN 978-0-7494-5242-1.

4. Beer, M., Spector B., Lawrence, P. R., Mills, D. Q., \& Walton, R. E. (1984). Managing Human Assets. New York: The Free Press, 209 p.

5. Belas, J., Kmecova, I., \& Cepel, M. (2020). Availability of human capital and the development of the public infrastructure in the context of business activities of SMEs. Administratie si Management Public 2020(34), 27-44

6. Carter, V. A., \& Donohue, M. (2012). Whole Person Learning: Embedding Ethical Enterprise Leadership In Business Education. American Journal Of Business Education, 5(6), 677-692.

7. Delery, J. E., \& Doty, D. H. (1996). Modes of theorizing in strategic human resource management: Tests of universalistic, contingency, and configurational performance 
predictions. Academy of Management Journal, 39(4), 802-835.

8. Efron, Bradley. (1992). Bootstrap methods: another look at the jackknife. Breakthroughs in Statistics: 569-593. Springer New York.

9. Gelens, J., Hofmans, J., Dries, N. \& Pepermans, R. (2014). Talent management and organisational justice: Employee reactions to high potential identification. Human Resource Management Journal, 24(2), 159-175.

10. Kleina, D., \& Štāle, S. (2019). Motivational Factors of Employees in Latvian Labor Market. Vadyba Journal of Management 35 (2), 27-32

11. Kruss, G., Mcgrath, S., Petersen, I. H., \& Gastrow, M. (2015). Higher education and economic development: The importance of building technological capabilities. International Journal of Educational Development, 43, 22-31. doi: 10.1016/j.ijedudev.2015.04.011.

12. Ližbetinová, L., \& Hitka, M. (2020). Gender motivation differences of Czech and Chinese employees. Periodica Polytechnica Social and Management Sciences 28(1), 48-58. doi: 10.3311/PPso.12867

13. Massingham, P. (2015). Knowledge Sharing: What Works and What Doesn't Work: A Critical Systems Thinking Perspective. Systemic Practice and Action Research, 28(3), 197-228.

14. Mcdonnell, A., Lavelle, J., \& Gunnigle, P. (2014). Human Resource Management in Multinational Enterprises: Evidence From a Late Industrializing Economy. Management International Review, 54(3), 361-380.

15. Močarníková, K., Mucha, B., \& Peráček, T. (2018). The importance and position of public company in the Slovak business law. Proceedings of the 31st International Business Information Management Association Conference, IBIMA 2018: Innovation Management and Education Excellence through Vision 2020, 3494-3502

16. Mura, L., \& Vlacseková, D. (2018). Motivation of public employees: Case study of slovak teaching and professional staff. Administratie si Management Public 2018 (31), 67-80

17. Peráček, T., Mucha, B., Brestovanská, P., \& Kajanová, J. (2018). Simple company on shares as startup support tool. Acta Universitatis Agriculturae et Silviculturae Mendelianae Brunensis 66(6), 1601-1611

18. Pfeffer, J. 1998. The human equation: Building profits by putting people first. Boston: Harvard Business School Press.

19. Schlechter, A., Hung, A., \& Bussin, M. (2014). Understanding talent attraction: the influence of financial rewards elements on perceived job attractiveness: original research. SA Journal of Human Resource Management, 12(1), 1-13.

20. Singh, R., Ragins, B. R., \& Tharenou, P. (2009). Who gets a mentor? A longitudinal assessment of the riding star hypothesis. Journal of Vocational Behavior, 2009, 74(1), 11-17.

21. Spiwok, V. (2015). Statistická analysa dat v R. Praha: VŠCHT. Dostupné z: <https:// web.vscht.cz/ spiwokv/statistika/skripta.pdf >.

22. Stone, D. L., Deadrick, D. L., Lukaszewski, K. M., \& Johnson, R. (2015). The influence of technology on the future of human resource management. Human Resource Management Review, 25(2), 216-231.

23. Swailes, S., \& Blackburn, M. (2016). Employee reactions to talent pool membership. Employee Relations, 38(1), 112-128.

24. Szeiner, Z., Mura, L., Horbulák, Z., Roberson, M., \& Poór, J. (2020). Management consulting trends in Slovakia in the light of global and regional tendencies. Journal of Eastern European and Central Asian Research 7(2), 191-204

25. Tan, A. G. (2013). Psychology of cultivating creativity in teaching and learning. 
Creativity, Talent and Excellence, 27-42. Springer Singapore.

26. Tetik, S. (2017). Talent Management: A Review of Theoretical Perspectives and a Guideline for Practioners. Nile. Journal of Business and Economics, 2(4), 40-56.

27. Wang, X. (2016). Human Resources Management of Enterprises. The Time of New Economy. 2016, 184-188.

\section{Correspondence address:}

doc. RNDr. Zuzana Hajduová, PhD., MSc., University of Economics in Bratislava, Faculty of Business Management, Department of Corporate Finance, Dolnozemská cesta 1/b, 85235 Bratislava, Slovakia. e-mail: zuzana.hajduova@euba.sk

Mgr. Fratišek Sebestyén, University of Economics in Bratislava, Faculty of Business Management, Department of Corporate Finance, Dolnozemská cesta 1/b, 85235 Bratislava, Slovakia. e-mail: frantisek.sebestyen@euba.sk 